\title{
Study on the putative active site of Enterococcus faecalis prolyl- tRNA synthetase editing domain by methods of site-directed mutagenesis
}

\author{
K. S. Boyarshin, I. A. Kriklivyi, A. V. Rayevsky, A. A. Himin, A. D. Yaremchuk, \\ M. A. Tukalo
}

Institute of Molecular Biology and Genetics, NAS of Ukraine 150 Academician Zabolotny Str., Kyiv 03680 Ukraine

kboyarshin@mail.ru

\begin{abstract}
The maintenance of amino acid specificity by aminoacyl-tRNA synthetases can require the hydrolysis of missynthesized products that is known as amino acid editing. Bacterial prolyl-tRNA synthetase includes a special editing domain, that deacylates alanyl-tRNA ${ }^{\text {Pro }}$, and so exhibits post-transfer editing activity. The mechanism of tRNA-dependent editing by prolyl-tRNA synthetase has to be defined. The present work aim is to study the structure of the active site of enterobacteria E. faecalis prolyl-tRNA synthetase editing domain. The amino acids positions E218, T257, K279, G331, S332, G334, and H366 have been chosen for the site-directed mutagenesis (alanine scanning). An editing activity of the mutants was compared with the wild type prolyl-tRNA synthetase. Three amino acid residues, important for the editing activity, K279, G331 and H366, were revealed. This data are consistent with the existing suppositions about the structure of bacterial prolyl-tRNA synthetase deacylating active site.
\end{abstract}

Keywords: prolyl-tRNA synthetase, editing, $t R N A$, site-directed mutagenesis.

Introduction. The maintenance of amino acid specificity by aminoacyl-tRNA synthetases may require not only specific recognition of amino acid, but also hydrolysis of missynthesized products that is known as amino acid editing. There are two ways of editing, namely, hydrolysis of missynthesized aminoacyl-adenylate (pre-transfer editing) and hydrolysis of missynthesized aminoacyl-tRNA (post-transfer editing) [1].

C) Institute of molecular biology and genetics NAS of Ukraine, 2009
Actually, the mechanisms of post-transfer editing by aminoacyl-tRNA synthetases of the first structural class are rather well-known [2-4], while the studies on analogous mechanisms for aminoacyl-tRNA synthetases of the second structural class, i.e. phenylalanyl[5] and treonyl-tRNA synthetases [6], are still in progress. However, the prolyl-tRNA synthetases post-transfer editing has been poorly investigated.

Bacterial prolyl-tRNA synthetases are able to perform the pre- and post-transfer alanine editing [7], which takes place in specialised editing domain, called 


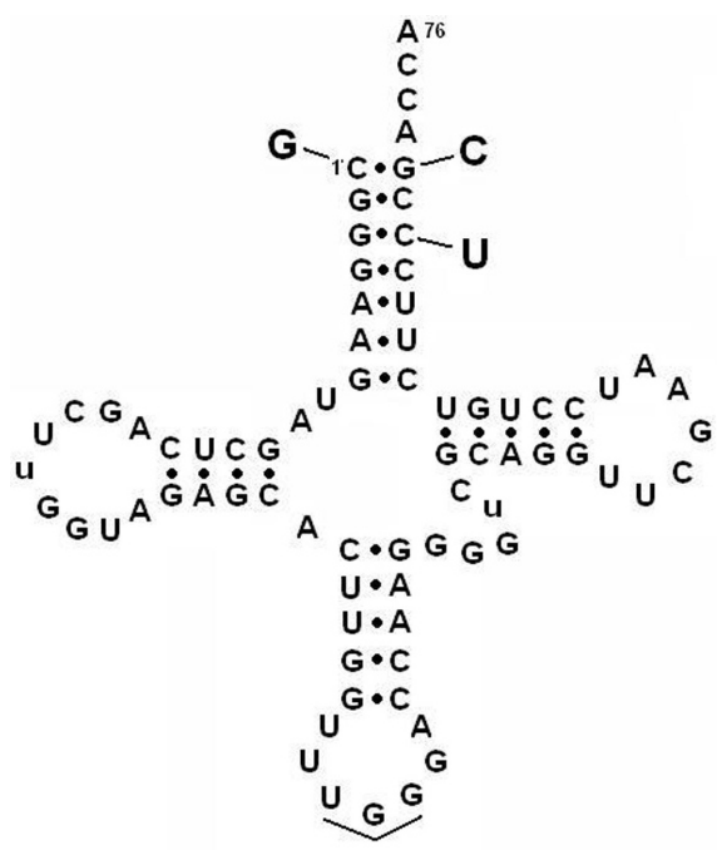

Fig.1. Mutant E. faecalis tRNA ${ }^{\text {Pro }}\left(\mathrm{tRNA}^{\text {ProAla }}\right)$. Recognition elements for alanyl-tRNA synthetase introduced in the sequence of wild type tRNA ${ }^{\text {Pro }}$ are indicated. Nucleotides of anticodon are underlined.

INS (insertion) [8, 9]. The current results of site-directed mutagenesis (for the Escherichia coli enzyme) [10] and structural data (for the E. faecalis enzyme) [11] allowed us to make some assumptions about location and structural organisation of the bacterial prolyl-tRNA synthetase deacylating site. For the $E$. coli enzyme, a particular importance for the efficiency and specificity of post-transfer editing of conservative lysine K279 and conservative histidine H369 has been shown and their participation in the formation of deacylating active site has been supposed [10]. Based on the structural data a possible role of conservative lysine K279, glycine G331, and histidine H366 as structural and functional elements of the E. feacalis deacylating active site has been suggested [11]. The aim of current work was to verify these suggestions as well as to compare the degree of similarity between the post-transfer editing mechanisms for the enzymes of phylogenetically distant bacteria: E. faecalis (Firmicutes type) and E. coli (Proteobacteria type).

Materials and Methods. The mutagenesis kit (Stratagene,USA), plasmid DNA extraction kit (Qiagene, USA), chromatographic matrixes
(Pharmacia Biotech, Sweden; Toyo Soda, Japan), amino acids (Pierce, France), radioactively marked substances (Amersham, UK), fibreglass filters (Whatman, USA), PEI-cellulose (Merck, Germany) were used in the work.

Creation of chimeric tRNA ${ }^{\text {Prosla }}$ and mutant forms of E. faecalis prolyl-tRNA synthetase. Mutagenesis of E. feacalis $\mathrm{tRNA}^{\text {Pro }}$ gene inserted into $p U C 18$ vector, containing T7-promoter, in order to introduce the recognition elements of alanyl-tRNA synthetase into its sequence (Fig. 1), was performed by QuickChange method (Stratagene) [12] using polymerase chain reaction (PCR). All mutant genes were checked by sequencing. In vitro transription and isolation of tRNA $^{\text {ProAla }}$ mutants were performed similarly to those for E. feacalis tRNA ${ }^{\text {Pro }}$ as previously described in [12], except for the co-expression of tRNA with cys-hydrolytic ribosyme.

Mutagenesis of E. faecalis prolyl-tRNA synthetase gene was accomplished by QuickChange method (Stratagene) [13], isolation and purification of mutant proteins were done as described in [12].

Analysis of aminoacylation. $130 \mu \mathrm{l}$ of reaction mixture contained $100 \mathrm{mM}$ tris- $\mathrm{HCl}, \mathrm{pH} 8.0,20 \mathrm{mM}$ $\mathrm{MgCl}_{2}, 0.5 \mathrm{mg} / \mathrm{ml} \mathrm{BSA}, 3 \mathrm{mM}$ ATP, $3 \mathrm{mM}$ proline, 20 $\mu \mathrm{M}{ }^{14} \mathrm{C}$-labelled proline $(85.0 \mathrm{mCi} / \mathrm{mmol}), 5$ or $10 \mu \mathrm{M}$ tRNA $^{\text {Pro }}$ (CGG) Rhodopseudomonas palustris and 5 $\mathrm{nM}$ prolyl-tRNA synthetase or its mutant forms. Aliquots of $20 \mu \mathrm{l}$ were taken from the reaction mixture incubated at $37^{\circ} \mathrm{C}$ and put into $200 \mu$ l of cold $10 \%$ TCA for tRNA and aminoacyl-tRNA precipitation. Then precipitates were transferred onto fibreglass filters, washed with $50 \mathrm{ml}$ 5\% TCA, dried and radioactivity counted in liquid scintillation counter.

Aminoacylation of $t R N A^{\text {Prosla }}$ by ${ }^{14} \mathrm{C}$-labelled alanine. $0.5 \mathrm{ml}$ alanine-tRNA ${ }^{\text {ProAla }}$ were obtained at the following concentrations of reaction mixture constituents: $600 \mathrm{nM}$ alanyl-tRNA synthetase from Thermus thermophilus, $15 \mu \mathrm{M}$ tRNA ${ }^{\text {ProAla }}, 0.03 \mathrm{mM}$ alanine, 78 $\mu \mathrm{M}{ }^{14} \mathrm{C}$-labelled alanine, $100 \mathrm{mM}$ tris- $\mathrm{HCl}, \mathrm{pH} 7.5,15$ $\mathrm{mM} \mathrm{MgCl}, 0.5 \mathrm{mg} / \mathrm{ml}$ BSA, $3 \mathrm{mM}$ ATP. The mixture was incubated at $37^{\circ} \mathrm{C}$ for $20 \mathrm{~min}$ and acidified by sodium-acetate buffer with subsequent treatment by phenol and chloroform. After ethanol precipitation the pellet was dried and dissolved in $40 \mu 1$ of $0.1 \mathrm{M}$ sodium-acetate $\mathrm{pH} 4.0$ buffer solution. 


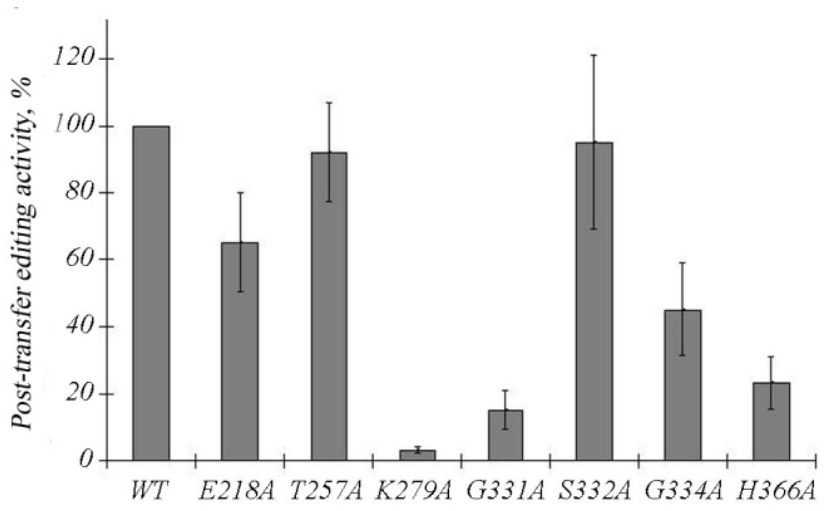

Fig.2. Post-transfer editing activity of wild type and mutant forms of E. faecalis prolyl-tRNA synthetase. Initial rate of deacylation reaction catalyzed by wild-type enzyme was taken as $100 \%$.

Alanyl-tRNA $A^{\text {Proala }}$ hydrolysis assay. $60 \mu \mathrm{l}$ of reaction mixture contained $60 \mathrm{nM}$ prolyl-tRNA synthetase of $E$. feacalis or its mutant forms, $100 \mathrm{mM}$ HEPES, $\mathrm{pH}$ 7.0, 10 $\mathrm{mM} \mathrm{MgCl}_{2}, 0.1 \mathrm{mg} / \mathrm{ml}$ BSA, $2 \mathrm{mM}$ dithiothreitol (DTT), $3 \mu$ l of ${ }^{14} \mathrm{C}$-alanyl-tRNA ${ }^{\text {ProAla }}$ solution, prepared as described above. Reaction was conducted at $37^{\circ} \mathrm{C}, 5$ $\mu 1$ aliquots were withdrawn at zero time-point and after $1,2,3,5,10 \mathrm{~min}$ of incubation, put on fibreglass filters, saturated by $10 \%$ TCA. Then filters were washed in $5 \%$ TCA, dried and analysed in liquid scintillation counter.

Analysis of ATP hydrolysis. $18 \mu \mathrm{l}$ of reaction mixture contained $100 \mathrm{mM}$ HEPES, $\mathrm{pH} 7.5,25 \mathrm{mM} \mathrm{KCl}$, $10 \mathrm{mM} \mathrm{MgCl} 2,2 \mathrm{mM}$ DTT, $1 \mathrm{mM}$ ATP, $75 \mu \mathrm{M}{ }^{14} \mathrm{C}$-labelled ATP $(57.9 \mathrm{mCi} / \mathrm{mmol}), 500 \mathrm{mM}$ alanine or 250 $\mathrm{mM}$ proline, $15 \mu \mathrm{M}$ tRNA ${ }^{\text {Pro }}$ and $2 \mu \mathrm{M}$ prolyl-tRNA synthetase. During incubation at $37^{\circ} \mathrm{C}, 2 \mu \mathrm{l}$ aliquots were taken out and put on PEI-cellulose. Then ATP, ADP, and AMP were separated by method of thin-layer chromatography in $0.75 \mathrm{M}$ potassium-phosphate buffer, pH 3.5. Radioactivity of ATP and AMP zones was analysed in liquid scintillation counter.

Results and Discussion. The following positions were selected for alanine scanning: T257, K279, H366, homologous to those which were already defined to be important for the post-transfer editing activity of $E$. coli prolyl-tRNA synthetase [10]; positions G331, S332, suggested as essential for the editing domain on the basis of structural data and computer simulation [11]; positions G334 and E218, located in the area of contact between editing domain and synthetic domain.
To check the editing activity of different mutant forms of prolyl-tRNA synthetase in alanyl-tRNA hydrolysis we created a hybrid tRNA, recognized by both proline and alanine aminoacyl-tRNA synthetases. Therefore, we introduced the recognition elements of tRNA specific for alanine into the sequence of tRNA specific for proline (Fig. 1).

The obtained chimerical tRNA was aminoacylated by labelled alanine. The editing activity of prolyl-tRNA synthetase mutant forms was estimated by the rate of labelled alanyl-tRNA hydrolysis. The data of initial rate of deacylation revealed that three out of seven isolated mutant forms of the enzyme (K279A, G331A, and H266A) showed significant (from 4 to 50 -fold) decreasing of post-transfer editing activity. K279A mutant demonstrated 2\% activity comparing to that of the wild type enzyme, G331A and H366A mutants $-16 \%$ and $24 \%$ respectively (Fig. 2).

For further investigation of mutant forms, showing significant decreasing of the post-transfer editing activity in deacylation assay, analysis of ATP hydrolysis, reflecting overall pre- and post-transfer editing (Fig. 3), and aminoacylation by homologous amino acid were conducted (Fig.4). The investigation of ATP hydrolysis in the presence of edited amino acid (alanine) revealed the same tendencies to a decline in the editing activity for different mutant forms of the enzyme. At the same time, the decreasing of aminoacylation activity of mutant forms does not correlate with the decreasing of editing activity, and is probably caused by induced conformational changes in the synthetic domain of prolyl-tRNA synthetase. These results allow us to conclude that mutations K279A, G331A, H366A specifically affect the post-transfer editing.

The data obtained confirm our previous assumption [11] about the structure of E. faecalis prolyl-tRNA synthetase deacylating active site, but they do not prove the role of amino acid residues T257 and S332, located close to the deacylating active site. K279 and H366, amino acid residues of E. feacalis prolyl-tRNA synthetase, which are homologous to K279 and H369 of $E$. coli, have similar [10] importance for hydrolysis of alanyl-tRNA ${ }^{\text {ProAla }}$ which emphasize the similarity of post-transfer editing mechanisms for prolyl-tRNA synthetases of both bacteria, in spite of their being somewhat phylogenetically distant. 


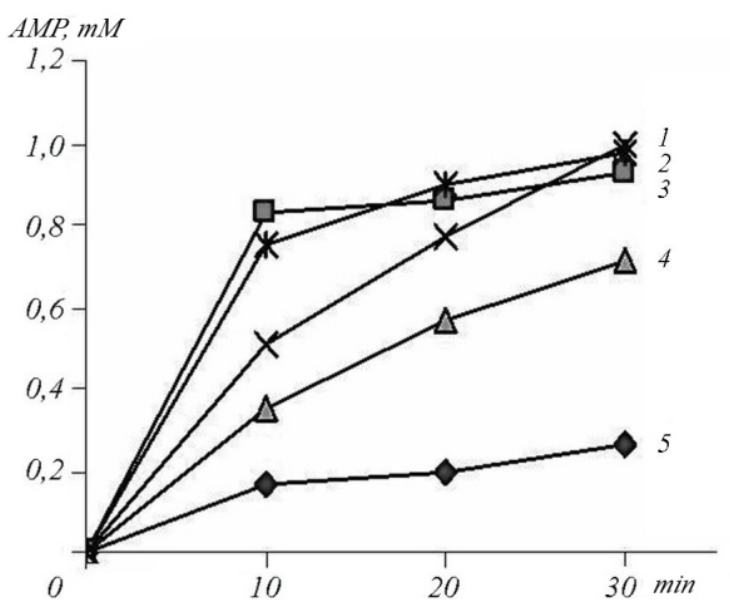

Fig.3. Editing against alanine performed by wild type E. faecalis (3) prolyl-tRNA synthetase and its mutant forms G331A (1), H366A (2), and K279A (4) in the presence of tRNA ${ }^{\text {Pro }} R$. palustris (CGG). Wild type enzyme without tRNA (5).

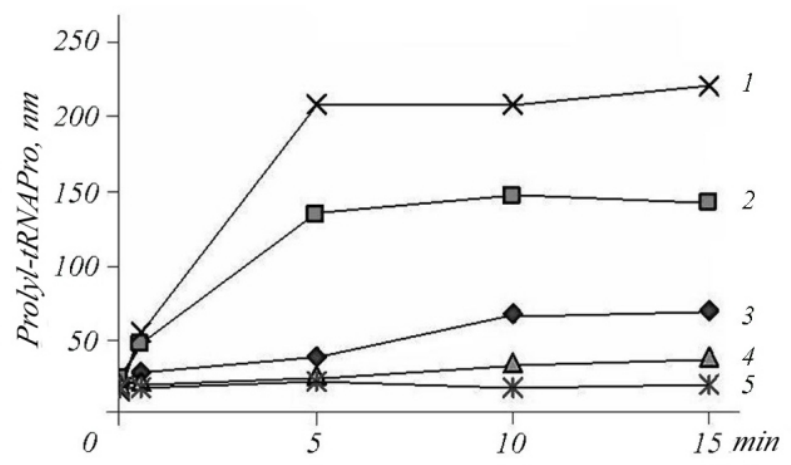

Fig.4. Kinetic of $R$. palustris tRNA ${ }^{\text {Pro }}$ (CGG) aminoacylation reaction catalyzed by the wild type E. faecalis prolyl-tRNA synthetase (1) and its mutant forms G331A (2), K279A (3), and H366A (4); 5 - without enzyme.

Structural data show that a side chain of lysine K279 is directed outside from all other amino acids of putative active centre and probably participates in the binding of acceptor end of alanyl-tRNA ${ }^{\text {Pro }}$ [11]. Similarly to $E$. feacalis prolyl-tRNA synthetase, a substitution of lysine K279 to alanine in the enzyme of E. coli [10] has the highest impact on the post-transfer editing activity compared to all studied amino acid residues, Apparently, this residue is positioning the substrate in the active centre of the editing domain, therefore, playing crucial role in the post-transfer editing by enzyme.

Histidine H366 as well as glycine G331, forming hydrogen bond with its side chain, perhaps, maintains an optimal structure of the deacylating active centre.
The substitution of histidine $\mathrm{H} 369$ to alanine or cysteine in $E$. coli enzyme resulted not only in dramatic decrease in the post-transfer editing activity, but also in disruption of deacylation specificity and hydrolysis of prolyl-tRNA ${ }^{\text {Pro }}$ as well [10]. The recognition of a bigger substrate by such mutant forms of the enzyme may point out on the disruption of the pocket integrity, where the editing amino acid residue is located [10, 11]. The same event may influence both substrate binding and catalysis efficiency which explains the decreasing in the post-transfer activity.

In conclusion, we can suggest that it is unlikely for a side chain of any studied amino acid residue to participate directly in the catalysis of deacylation reaction. At the same time one cannot deny that chemical groups of the main chain some of these amino acids play a significant role in coordination of the ion or water molecules, that are responsible for catalysis. In any case, the mechanism of alanyl-tRNA ${ }^{\text {Pro }}$ deacylation in the editing domain active centre of bacterial prolyl-tRNA synthetases is yet to be defined.

К. С. Бояршин, И. А. Крикливыцй, А. В. Раевский, А. А. Химин, А. Д. Яремчук, М. А. Тукало

Предполагаемый активный центр редактирующего домена пролил-тРНК синтетазы бактерии Enterococcus faecalis

Резюме

Обеспечение аминокислотной специфичности аминоаиил-тРНК синтетаз в ряде случаев требует проведения гидролиза ошибочно синтезированных продуктов, известного как аминокислотное редактирование. Бактериальные пролил-тРНК синтетазы содержат специальный редактирующзий домен, деацилирующий аланил-тРНК ${ }^{\text {Pro }}$ и таким образом демонстрирующий посттрансферную редактирующую активность. Механизм тРНК-зависимого редактирования пролил-тРНК синтетазой остается нераскрытым. Цель настоящей работы состояла в изучении структуры активного иентра редактирующего домена пролил-тРНК синтетазы E. faecalis. Аминокислотные позиции E218, T257, K279, G331, S332, G334, H366 избраны для сайт-направленного мутагенеза (аланинового сканирования), а редактирующая активность мутантных форм сопоставлена с диким типом пролил-тРНК синтетазы. Выявлены три аминокислотных остатка, имеющих значение для посттрансферной редактирующей активности фермента, - K279, G331 и Н366. Полученные данные подтверждают существующие предположения о структуре активного иентра редактируюшего домена бактериальных пролил-тРНК синтетаз.

Ключевые слова: пролил-тРНК синтетаза, редактирование, тРНК, сайт-направленный мутагенез. 
К. С. Бояршин, І. А. Крикливий, О. В. Раєвський, А. О. Хімін, Г. Д. Яремчук, М. А.Тукало

Передбачуваний активний центр редагуючого домену пролілтРНК синтетази бактерії Enterococcus faecalis

\section{Резюме}

Забезпечення амінокислотної специфічності аміноацил-тРНК синтетаз інколи потребуе проведення гідролізу помилково синтезованих продуктів, відомого як амінокислотне редагування. Бактеріальні проліл-тРНК синтетази містять спеціальний

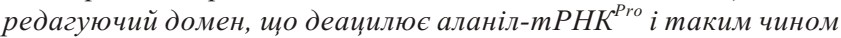
проявляє посттрансферну редагуючу активність. Механізм МРНК-залежного редагування проліл-тРНК синтетазою лишається невстановленим. Мета иієї роботи полягала у визначенні структури активного иентра редагуючого домену проліл-тРНК синтетази E. faecalis. Амінокислотні позииії E218, T257, K279, G331, S332, G334, H366 обрано для сайт-спрямованого мутагенезу (аланінового сканування), а редагуючу активність мутантних форм зіставлено $з$ активністю проліл-тРНК синтетази дикого типу. Знайдено три амінокислотних залишки, важливі для посттрансферної редагуючої активності ферменту, - K279, G331 і H366. Отримані дані підтверджують існуючі припущення щодо структури активного иеетра редагуючого домену бактеріальних пролілтРНК синтетаз.

Ключові слова: проліл-тРНК синтетаза, редагування, тРНК, сайт-спрямований мутагенез.

\section{REFERENCES}

1. Jakubowski H., Goldman E. Editing of errors in selection of amino acids for protein synthesis // Microbiol. Rev.-1992.56, N 3.-P. 412-429.

2. Lincecum T. L., Tukalo M., Yaremchuk A., Mursinna R. S., Williams A. M., Sproat B. S., Van Den Eynde W., Link A., Van Calenbergh S., Grotli M., Martinis S. A., Cusack S. Structural and mechanistic basis of pre- and posttransfer editing by leucyl-tRNA synthetase // Mol. Cell.-2003.-11, N 4.- P. 951963.

3. Fukunaga R., Yokoyama S. Structural basis for non-cognate amino acid discrimination by the valyl-tRNA synthetase edi- ting domain // J. Biol. Chem.-2005.-280, N 33.-P. 2993729945.

4. Fukunaga R., Yokoyama S. Structural basis for substrate recognition by the editing domain of isoleucyl-tRNA synthetase // J. Mol. Biol.-2006.-359, N 4.-P. 901-912.

5. Sasaki H. M., Sekine S., Sengoku T., Fukunaga R., Hattori M., Utsunomiya Y., Kuroishi C., Kuramitsu S., Shirouzu M., Yokoyama S. Structural and mutational studies of the amino acid-editing domain from archaeal/eukaryal phenylalanyltRNA synthetase // Proc. Nat. Acad. Sci. USA.-2006.-103, N 40.-P. 14744-14749.

6. Waas W. F., Schimmel P. Evidence that tRNA synthetasedirected proton transfer stops mistranslation // Biochemistry.-2007.-46, N 43.-P. 12062-12070.

7. Beuning P. J., Musier-Forsyth K. Hydrolytic editing by a class II aminoacyl-tRNA synthetase // Proc. Nat. Acad. Sci. USA.-2000.-97, N 16.-P. 8916-8920.

8. Wong F. C., Beuning J., Silvers C., Musier-Forsyth K. An isolated class II aminoacyl-tRNA synthetase insertion domain is functional in amino acid editing // J. Biol. Chem.2003.-278, N 52.-P. 52857-52864.

9. Hati S., Ziervogel B., SternJohn J., Wong F. C., Nagan M. C., Rosen A. E., Siliciano P. G., Chihade J. W., Musier-Forsyth $K$. Pre-transfer editing by class II prolyl-tRNA synthetase: role of aminoacylation active site in "selective release» of noncognate amino acids // J. Biol. Chem.-2006.-281, N 38.P. 27862-27872.

10. Wong F. C., Beuning P. J., Nagan M., Shiba K., MusierForsyth $K$. Functional role of the proline-tRNA synthetase insertion domain in amino acid editing // Biochemistry.2002.-41, N 22.-P. 7108-7115.

11. Crepin T., Yaremchuk A., Tukalo M., Cusack S. Structures of two bacterial prolyl-tRNA synthetases with and without a cis-editing domain // Structure.-2006.-14.-P. 1511-1525.

12.Boyarshin K. S., Kriklivyi I. A., Tukalo M. A. tRNA-dependent editing of errors by prolyl-tRNA synthetase from bacteria Enterococcus faecalis // Ukr. Biochem. J.- 2008.-79, N 6.-P. 40-44.

13. QuikChange ${ }^{\circledR}$ XL Site-Directed Mutagenesis Kit, instruction manual, catalog \#200516.-La Jolla, 2005.-P. 1-15.

UDC 577.217.32

Received 25.09.07 